Atmos. Chem. Phys., 10, 3205-3213, 2010

www.atmos-chem-phys.net/10/3205/2010/

(C) Author(s) 2010. This work is distributed under

the Creative Commons Attribution 3.0 License.

\title{
Technical Note: A new coupled system for global-to-regional downscaling of $\mathrm{CO}_{2}$ concentration estimation
}

\author{
K. Trusilova, C. Rödenbeck, C. Gerbig, and M. Heimann \\ Max-Planck Institute for Biogeochemistry, Hans-Knoell Str. 10, Jena, Germany \\ Received: 30 July 2009 - Published in Atmos. Chem. Phys. Discuss.: 2 November 2009 \\ Revised: 5 March 2010 - Accepted: 24 March 2010 - Published: 1 April 2010
}

\begin{abstract}
We introduce a global-to-regional nesting scheme for atmospheric transport models used in simulating concentrations of green house gases from globally distributed surface fluxes. The coupled system of the regional Stochastic Time-Inverted Lagrangian Transport (STILT) model and the global atmospheric transport model (TM3) is designed to resolve atmospheric trace gas concentrations at high temporal and spatial resolutions in a specified domain e.g. for regional inverse applications. The nesting technique used for the coupling is based on a decomposition of the atmospheric concentration signal into a far-field and a near-field contribution enabling the usage of different model types for global (Eulerian) and regional (Lagrangian) scales. For illustrating the performance of the coupled TM3-STILT system we compare simulated mixing ratios of carbon dioxide with available observations at 10 sites in Europe. For all chosen sites the TM3STILT provided higher correlations between the modelled and the measured time series than the TM3 global model. Autocorrelation analysis demonstrated that the TM3-STILT model captured temporal variability of measured tracer concentrations better than TM3 at most sites.
\end{abstract}

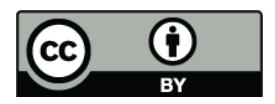

Correspondence to: $\mathrm{K}$. Trusilova (ktrusil@bgc-jena.mpg.de)

\section{Introduction}

Anthropogenic and biogenic emissions of trace gases at the surface cause large variations of atmospheric concentrations in the Planetary Boundary Layer (PBL), and upstream sources and sinks influence tracer mixing ratios at observational stations. However, the scales on which the transport in this "near-field" often takes place are not resolved by typical grid sizes of global atmospheric transport models. The comparison against available observations is therefore difficult and often requires averaging of the observed quantities in time and space to the model resolution. Such averaging leads to a loss of information about fine scale signals that can be retrieved from trace gas fluxes at high temporal and spatial resolutions by an atmospheric inverse scheme (Lin and Gerbig, 2005; Gerbig et al., 2008).

In order to refine the spatial and temporal resolutions of the predicted concentrations of trace gases in global transport models, domain nesting techniques are often used. Such a zooming technique was implemented in the atmospheric chemistry-transport zoom model TM5 (Krol et al., 2005) and in the nested regional transport-chemistry model HANK (Hess et al., 2000). In order to smooth the transition from the global grid of several degrees to a fine grid of less than $1^{\circ} \times 1^{\circ}$ typically, often one or more intermediate zoom regions are needed. This multi-domain nesting leads to an increased computational cost of model runs and can be justified only when the whole zoomed area is of interest. However, for a model evaluation or an inverse model study, usually

Published by Copernicus Publications on behalf of the European Geosciences Union. 
only the model output at a limited number of available observation locations is required. Such a local refinement of the spatial resolution for predicted variables may be achieved by using Lagrangian transport models (Rotach et al., 1996; Lin et al., 2003; Stohl et al., 2005; Pongratz et al., 2008) for calculating the footprint (near-field) and background (far-field) influences for each available observation. Lagrangian transport models simulate transport by following the time evolution of a particle ensemble and interpolating meteorological fields to the sub-grid scale location of each particle. The particle approach can provide significant gains in information as compared to Eulerian-grid models due to the adjustable time step and fine spatial resolution of surface sources and sinks (Lin et al., 2003).

In this paper, we present a new fully coupled system of a global three-dimensional atmospheric tracer model and a stochastic Lagrangian transport model designed for predicting atmospheric trace gas concentrations at fine temporal and spatial resolutions. The coupled system is to be used in the two-step scheme for high-resolution regional atmospheric trace gas inversions described in the work of Rödenbeck et al. (2009). This scheme allows coupling of two independent atmospheric transport models for retrieving surface fluxes of observed trace gases at finer regional spatial resolutions than possible with global models. Rödenbeck et al. (2009) presented the scheme using a hypothetical regional model nested into the global one; here we demonstrate an implementation of the coupled system consisting of a global Eulerian grid model and a regional Lagrangian model to be used in this scheme. In this study we analyse the performance of the coupled system for the European domain and evaluate it against continuous measurements of $\mathrm{CO}_{2}$ concentrations at 10 European sites.

\section{Modelling system}

The global-regional coupled system of the global Euleriangrid and the regional Lagrangian atmospheric transport models is highly modular and both components can be decoupled at the stage of compilation. The technical implementation of the coupling is consistent and it is based on the principle of decomposition of measured tracer mixing ratio on the "near-field" and "far-field" contributions. This decomposition is possible because of the linearity of the atmospheric continuity equation for a conservative tracer. The near-field part of the signal is resolved by the fine-scale regional model whereas the far-field part - the relatively well-mixed atmosphere background - is resolved by the global coarse-grid model.

The global atmospheric tracer model TM3 (Heimann and Körner, 2003) is a three-dimensional transport model that solves the continuity equation for an arbitrary number of atmospheric tracers. It uses prescribed meteorological fields, which can be obtained from an atmospheric general circulation model or from a weather forecast model. 6 hourly meteorological fields from the NCEP/NCAR Global Reanalysis Products (Kalnay et al., 1996) were used for our simulations.

The Stochastic Time-Inverted Lagrangian Transport model STILT (Gerbig et al., 2003; Lin et al., 2003) simulates atmospheric transport by following the time evolution of a particle ensemble backwards in time and calculates footprint elements that represent the sensitivity of the mixing ratio of the tracer at the receptor location to any given surface flux. The model uses meteorological fields from the ECMWF ${ }^{1}$ operational data at the spatial resolution of 0.25 degree horizontally with 60 vertical levels on the latitude/longitude projection that have been obtained from the ECMWF Data Server. The particle number was set to 100 (per receptor point), providing the statistical error of $\sim 13 \%$ of the regional contribution to the $\mathrm{CO}_{2}$ mixing ratio at the receptor point (Gerbig et al., 2003). As described by Lin et al. (2003), STILT computes the influence function $I\left(x_{\mathrm{r}}, t_{\mathrm{r}} \mid x, t\right)$, which links the local concentration $C\left(x_{\mathrm{r}}, t_{\mathrm{r}}\right)$ of a tracer, measured at receptor location $x_{\mathrm{r}}$ at time $t_{\mathrm{r}}$ to the surface sources $S(x, t)$ of the tracer (in ppm units) emitted at locations $x$ at time $t$ into a shallow layer near the surface:

$$
\begin{aligned}
& C\left(x_{\mathrm{r}}, t_{\mathrm{r}}\right)=\Delta C\left(x_{\mathrm{r}}, t_{\mathrm{r}}\right)_{\mathrm{NF}}+C\left(x_{\mathrm{r}}, t_{\mathrm{r}}\right)_{\mathrm{FF}} \\
& \Delta C\left(x_{\mathrm{r}}, t_{\mathrm{r}}\right)_{\mathrm{NF}}=\int_{t_{0}(x)}^{t_{\mathrm{r}}} d t \int_{V} d^{3} x I\left(x_{\mathrm{r}}, t_{\mathrm{r}} \mid x, t\right) S(x, t) \\
& C\left(x_{\mathrm{r}}, t_{\mathrm{r}}\right)_{\mathrm{FF}}=\int_{V} d^{3} x I\left(x_{\mathrm{r}}, t_{\mathrm{r}} \mid x, t_{0}(x)\right) C\left(x, t_{0}(x)\right)
\end{aligned}
$$

The first term on the right-hand side in Eq. (1), $\Delta C\left(x_{\mathrm{r}}, t_{\mathrm{r}}\right)_{\mathrm{NF}}$, represents the upstream near-field influence to the concentration at the receptor location. The function $I\left(x_{\mathrm{r}}, t_{\mathrm{r}} \mid x, t\right)$ links volumetric sources $S(x, t)$ to the concentrations at the receptor $C\left(x_{\mathrm{r}}, t_{\mathrm{r}}\right)$. The layer, which is considered to be in contact with the surface, is as thick as $50 \%$ of the local mixing height. The term $\Delta C\left(x_{\mathrm{r}}, t_{\mathrm{r}}\right)_{\mathrm{NF}}$ is calculated along trajectories of particles while they "interact" with the surface layer and the corresponding air parcels exchange tracers with surface sources and sinks. A trajectory of a particle is the path followed by the particle along the mean wind direction starting at the location (receptor) at time $t_{\mathrm{r}}$. The trajectory length is limited by the maximum backward time of calculation, $t_{0}(x) \leq 72$ (hours) for this study, and by the limits of the regional model domain.

The second term in Eq. (1), $C\left(x_{\mathrm{r}}, t_{\mathrm{r}}\right)_{\mathrm{FF}}$, represents the influence of the background concentration of the given tracer to its concentration at the receptor. This background far-field $\mathrm{CO}_{2}$ concentration is calculated by the global model.

\footnotetext{
${ }^{1}$ The European Centre for Medium-Range Weather Forecasts, http://www.ecmwf.int/
} 


\section{Model simulations}

Two domains were defined for the model simulations: the Global Domain (GD) with $72 \times 48$ grid cells on the spatial resolution of $4^{\circ} \times 5^{\circ}$, and the regional domain of interest (DoI) covering central and western Europe from $12^{\circ} \mathrm{W}$ to $35^{\circ} \mathrm{E}$ and from $35^{\circ} \mathrm{N}$ and $62^{\circ} \mathrm{N}$ with $108 \times 188$ (latitude by longitude) grid cells corresponding to a spatial resolution of $0.25^{\circ} \times 0.25^{\circ}$ of the tracer flux field. The layout of the two grids is shown in Fig. 1. The full period of simulations (FP) extends from 1 January 2005 to 1 January 2007 for the global model. The period of interest (PoI) extends from 1 March to 31 October 2006. The time between 1 January 2005 and 1 March 2006 is the spinup time used in the global model to acquire the initial background distribution of the trace gas mixing ratios at the beginning of PoI.

We compare the performance of the global TM3 model versus the regional TM3-STILT coupled model within the DoI/PoI. The far-field influence $C_{\mathrm{FF}}$ is the same for both model simulations, whereas the near-field $\left(C_{\mathrm{NF}}\right)$ contributions resolved by the global and the regional models differ.

The $C_{\mathrm{NF}}$ value was sampled from both models in the following way: the sampling level in the TM3 model was defined above the sea level at which the mixing ratio of the corresponding grid cell was taken; the sampling height in the STILT model was defined above the ground level. Values of $C_{\mathrm{NF}}$ from both models were compared to $C_{\mathrm{NF}}$ extracted from observations.

\subsection{Calculating the far-field part of the mixing ratio signal}

The far-field part of the signal $C_{\mathrm{FF}}$ is calculated by the global model in two steps as in the 2-step inversion scheme (Rödenbeck et al., 2009):

1. the global three-dimensional distribution of carbon dioxide mixing ratio in the atmosphere $\left(C_{\text {glob }}\right)$ for GD/FP is calculated with the global TM3 model using an inversion-retrieved estimate of the carbon surface flux $\left(F_{\text {posterior }}\right)$;

2. the near-field contribution in the global simulation is subtracted from the global $\mathrm{CO}_{2}$ field $C_{\text {glob }}$.

For retrieving $F_{\text {posterior }}$ we used an inversion similar to the global inversion described in the work of Rödenbeck (2005) but with the following prior estimates of global surface flux fields: the anthropogenic emission fields taken from the EDGARv3.2 emission database (Olivier et al., 2005; van Aardenne et al., 2005) that was linearly extrapolated to 2006, the net biosphere-atmosphere exchange calculated with the terrestrial ecosystem model BIOME-BGC (Trusilova and Churkina, 2008), and the net ocean-atmosphere carbon flux $\left(F_{\mathrm{o}}\right)$ that was specified as the sum of the ocean uptake flux induced by the anthropogenic perturbation as compiled

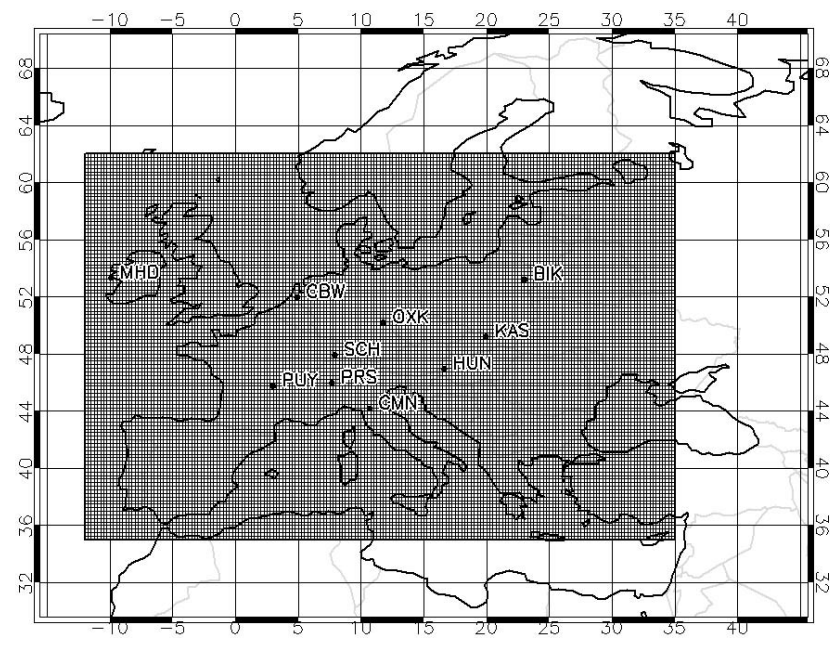

Fig. 1. The global and the regional domains.

by Mikaloff-Fletcher et al. (2006), the preindustrial air-sea fluxes from Mikaloff-Fletcher et al. (2007), and the river fluxes of Jacobson et al. (2007). The inversion used the observed mixing ratios $C_{\mathrm{obs}}$ at a global set of monitoring stations as the primary input.

For calculating the $C_{\text {glob }}$ in the global forward simulation we use the $F_{\text {posterior as determined by the global atmospheric }}$ inversion over the GD/FP.

In order to estimate in the European region the far-field contribution $C_{\mathrm{FF}}$ only, the near-field regional contribution $C_{\mathrm{NF}}$ has to be subtracted from the $C_{\mathrm{glob}}$. The $C_{\mathrm{NF}}$ is calculated with the global model within the DoI/PoI using the modified flux input $F_{\text {posterior_}} 0=\left\{F_{\text {posterior }}\right.$ within DoI $/ \mathrm{PoI} ; 0-$ otherwise\}. Finally, the remaining $C_{\mathrm{FF}}$ is calculated as:

$C_{\mathrm{FF}}=C_{\mathrm{glob}}-C_{\mathrm{NF}}=A_{\mathrm{TM} 3} F_{\text {posterior }}-A^{\prime}{ }_{\mathrm{TM} 3} F_{\text {posterior_0 }}$,

where $A_{\mathrm{TM} 3}$ is linear transport operator of the global model; $A^{\prime}{ }_{\text {TM}} 3$ is the transport operator of the global model, $A_{\mathrm{TM} 3}$, modified for the comparison with the regional model in the following way: any tracer emitted within the DoI/PoI and transported beyond the DoI/PoI cannot re-enter it; any tracer field outside $\mathrm{DoI} / \mathrm{PoI}$ is set to 0 in order to avoid double counting of the same tracer mass contribution to the near field (within the DoI/PoI) and to the far field (outside the DoI/PoI). The near field signal $C_{\mathrm{NF}}$ has to be subtracted from $C_{\mathrm{FF}}$ in order to avoid double counting of the near field influence in the global atmosphere.

The far-field mixing ratio $C_{\mathrm{FF}}$ is calculated using the optimized surface flux estimate $F_{\text {posterior }}$ retrieved by a global atmospheric inversion in a previous step. This guarantees that the global flux field, $F_{\text {posterior }}$ and, subsequently, the $C_{\mathrm{FF}}$ are consistent with the observations globally. With this procedure, $C_{\mathrm{FF}}$ is a good coarse scale estimate of the far-field influence given by the global atmospheric transport model. 


\subsection{Calculating the near-field part of the mixing ratio signal}

The near-field contribution resolved by the global and the regional models $-C_{\mathrm{NF}_{-} \mathrm{TM} 3}$ and $C_{\mathrm{NF}_{3} \mathrm{STILT}}$, respectively - are calculated within DoI/PoI with the set of fluxes $F$ upscaled to spatial resolutions of $4^{\circ} \times 5^{\circ}$ and $0.25^{\circ} \times 0.25^{\circ}$ for the global model and the regional model:

$$
\begin{aligned}
& C_{\text {NF_TM3 }}=A_{\text {TM3 }}^{\prime} F \\
& C_{\text {NF_STILT }}=A_{\text {STILT }} F,
\end{aligned}
$$

where $A_{\text {STILT }}$ is the linear transport operator of the regional model.

For calculating $C_{\mathrm{NF}_{-} \mathrm{TM} 3}$ and $C_{\mathrm{NF} \_ \text {STILT }}$, three components of the carbon surface flux were specified with high temporal and spatial resolution: the anthropogenic carbon emission flux $\left(F_{\mathrm{a}}\right)$, the land biosphere $\left(F_{\mathrm{b}}\right)$ and the ocean $\left(F_{\mathrm{o}}\right)$ net carbon exchange fluxes. The $F_{\mathrm{a}}$ was derived from the European anthropogenic emission inventory at a resolution of $10 \mathrm{~km}$ (Pregger et al., 2007). The $F_{\mathrm{b} \_V P R M}$ was calculated with the diagnostic model VPRM (Mahadevan et al., 2008 ) for the DoI $/ \mathrm{PoI}$ at $1 / 12^{\circ} \times 1 / 8^{\circ}$. The VPRM model was driven with the ECMWF operational meteorological data and used the land cover classification database SYNMAP (Jung et al., 2006). The $F_{\mathrm{a}}$ and $F_{\mathrm{b}}$ were aggregated to the resolution $0.25^{\circ} \times 0.25^{\circ}$ for the DoI/PoI. The $F_{0}$, which was used in the global inversion discussed above, was re-sampled to $0.25^{\circ} \times 0.25^{\circ}$ within the DoI/PoI. The corresponding input files contain carbon emission fluxes $\left[\mathrm{mol} \mathrm{m}^{-2} 3 \mathrm{~h}^{-1}\right]$ on the latitude-longitude projection.

\section{Evaluation of the coupled TM3-STILT model}

For the evaluation of the models two simulations were performed for the DoI/PoI domain: (1) on the coarse spatial/temporal resolution with the TM3 model and (2) on the fine spatial resolution with the TM3-STILT coupled model.

The time series of the near-field $\mathrm{CO}_{2}$ mixing ratios, $C_{\text {NF_TM3 }}$ and $C_{\text {NF_STILT }}$, were then compared with the nearfield signal $\left(C_{\mathrm{NF}_{-} \text {obs }}\right)$ extracted from the time series of observations $\left(C_{\text {obs }}\right)$ that was estimated as:

$C_{\mathrm{NF} \_ \text {obs }}=C_{\mathrm{obs}}-C_{\mathrm{FF}}$

\subsection{Data selection}

As the coupled TM3-STILT system is designed for performing regional atmospheric inversions on high spatial resolutions, for the evaluation we chose the sites that will potentially be used in a regional inversion for the European domain (Table 1). The $\mathrm{CO}_{2}$ concentration data were provided by the measurement institutions listed in the Table 1. The data selection procedure for continuous and for flask data is described in the work of Rödenbeck (2005).
Although the measured and modelled data are continuous and of high frequency $(1 \mathrm{~h})$, we chose to analyse the model output only between 10:00 and 17:00 UTC in order not to include night time values because of several considerations:

1. the night-time mixing ratios near the surface, where the stations are located, are very much influenced by small scale meteorological circulation patterns which are mostly not resolved in either global or regional models;

2. the day-time values measured at tall towers or mountain stations are representative of the well-mixed planetary boundary layer and are better represented in atmospheric models.

\subsection{Subtraction of the seasonal signal}

The large-scale seasonal variability of the $\mathrm{CO}_{2}$ concentrations over Europe is dominated by the surface flux from the entire northern hemisphere, and which is represented primarily in the far-field component of the mixing ratio. Here the synoptic variability is of interest and, therefore, prior to the statistical analysis we subtracted the seasonal component from the observed and modelled time series. Otherwise, including the season cycle in the time series would increase the model-to-data match (due to correlations governed by the large scale seasonal patterns) but such approach would not allow a fair analysis of the role the transport scales play in representing the fine scale variability of trace gas signals.

A harmonic function was used to approximate the seasonal flux component for each time series:

$c(t)=c_{0}+c_{1} t+$

$\sum_{i=1}^{4}\left(a_{i} \sin \left(\frac{2 \pi}{365 d} i \cdot t\right)+b_{i} \cos \left(\frac{2 \pi}{365 d} i \cdot t\right)\right)$,

where $c(t)$ is time series of measured | modelled concentration values, $c_{0}, c_{1}, a_{i}, b_{i}$ are constants estimated by the harmonic-fitting algorithm. $t$ is time expressed in days of the year.

The seasonal signal approximated by the harmonic function $c(t)$ was subtracted from the time series $C_{\mathrm{NF}_{-} \mathrm{TM} 3}$, $C_{\mathrm{NF} \_ \text {STILT }}$, and $C_{\mathrm{NF}_{-} \text {obs. }}$. The resulting time series $X_{\mathrm{TM} 3}$, $X_{\mathrm{STILT}}$, and $X_{\mathrm{obs}}$ were then statistically analysed.

\subsection{Statistical measures for the model evaluation}

For comparing the performance of atmospheric transport models we calculated the correlation coefficient $(r)$ and the Root Mean Square Deviation (RMSD) between modelled and measured time series of $\mathrm{CO}_{2}$ (only for the near-field influence parts $X_{\mathrm{TM} 3}, X_{\mathrm{STILT}}$, and $X_{\mathrm{obs}}$ ), as well as the autocorrelation coefficient $(R)$ and the variance (Var) for these time series. 
Table 1. Sites with the $\mathrm{CO}_{2}$ concentration measurements for the validation of TM3 and TM3-STILT models.

\begin{tabular}{|c|c|c|c|c|c|c|}
\hline Code & $\begin{array}{l}\text { Name/Geographic } \\
\text { location }\end{array}$ & Latitude & Longitude & $\begin{array}{l}\text { Height } \\
\mathrm{m} \\
\text { a.s.1. }\end{array}$ & $\begin{array}{l}\text { Site } \\
\text { class }\end{array}$ & $\begin{array}{l}\text { Measurement } \\
\text { institution, } \\
\text { references }\end{array}$ \\
\hline BIK & Bialystok, Poland & $53^{\circ} 13^{\prime} \mathrm{N}$ & $23^{\circ} 01^{\prime} \mathrm{E}$ & 463 & $\mathrm{C}$ & $\begin{array}{l}\text { MPI-BGC }{ }^{1},(\text { Popa } \\
\text { et al., 2010) }\end{array}$ \\
\hline $\mathrm{CBW}$ & $\begin{array}{l}\text { Cabauw, The } \\
\text { Netherlands }\end{array}$ & $51^{\circ} 58^{\prime} \mathrm{N}$ & $4^{\circ} 55^{\prime} \mathrm{E}$ & 200 & $\mathrm{C}$ & $\mathrm{ECN}^{2}$ \\
\hline $\mathrm{CMN}$ & Monte Cimone, Italy & $44^{\circ} 11^{\prime} \mathrm{N}$ & $10^{\circ} 42^{\prime} \mathrm{E}$ & 2165 & M & $\begin{array}{l}\text { IAFMS }^{3},(\text { Cundari } \\
\text { et al., 1995) }\end{array}$ \\
\hline HUN & Hegyhatsal, Hungary & $46^{\circ} 57^{\prime} \mathrm{N}$ & $16^{\circ} 39^{\prime} \mathrm{E}$ & 363 & $\mathrm{C}$ & $\begin{array}{l}\text { OMSZ }^{4}, \text { (Haszpra } \\
\text { et al., 2008) }\end{array}$ \\
\hline KAS & $\begin{array}{l}\text { Kasprowy Wierch, } \\
\text { Poland }\end{array}$ & $49^{\circ} 13^{\prime} \mathrm{N}$ & $19^{\circ} 59^{\prime} \mathrm{E}$ & 1987 & M & $\begin{array}{l}\mathrm{AGH}^{5},(\mathrm{Necki} \\
\text { et al., 2003) }\end{array}$ \\
\hline MHD & Mace Head, Ireland & $53^{\circ} 19^{\prime} \mathrm{N}$ & $9^{\circ} 53^{\prime} \mathrm{W}$ & 25 & $\mathrm{~S}$ & $\begin{array}{l}\text { NUI Galway }{ }^{6} \text {, } \\
\text { (Derwent et al., } \\
\text { 2002) }\end{array}$ \\
\hline OXK & $\begin{array}{l}\text { Ochsenkopf, } \\
\text { Germany }\end{array}$ & $50^{\circ} 12^{\prime} \mathrm{N}$ & $11^{\circ} 48^{\prime} \mathrm{E}$ & 1183 & M & $\begin{array}{l}\text { MPI-BGC }{ }^{1}, \\
\text { (Thompson et al., } \\
\text { 2009) }\end{array}$ \\
\hline PRS & Plateau Rosa, Italy & $45^{\circ} 59^{\prime} \mathrm{N}$ & $7^{\circ} 42^{\prime} \mathrm{E}$ & 3480 & M & $\begin{array}{l}\text { ENEA }^{7}, \text { (Longhetto } \\
\text { et al., 1995) }\end{array}$ \\
\hline PUY & Puy de Dome, France & $45^{\circ} 45^{\prime} \mathrm{N}$ & $3^{\circ} 00^{\prime} \mathrm{E}$ & 1465 & M & $\begin{array}{l}\mathrm{LSCE}^{8}, \text { (Sturm } \\
\text { et al., 2005) }\end{array}$ \\
\hline $\mathrm{SCH}$ & $\begin{array}{l}\text { Schauinsland, } \\
\text { Germany }\end{array}$ & $47^{\circ} 55^{\prime} \mathrm{N}$ & $7^{\circ} 55^{\prime} \mathrm{E}$ & 1205 & M & $\begin{array}{l}\mathrm{UBA}^{9},(\text { Levin et } \\
\text { al., 1995; Schmidt } \\
\text { et al., 2003) }\end{array}$ \\
\hline
\end{tabular}

C - "Continental" - surface sites on continents;

M - "Mountain" - mountain sites (in continents);

$\mathrm{S}$ - "Shore" - at land/sea interface;

1 MPI-BGC - Max-Planck Institute for Biogeochemistry, Germany (www.bgc-jena.mpg.de)

${ }^{2}$ ECN - Energy Research Centre of the Netherlands (www.ecn.nl)

${ }^{3}$ IAFMS - Italian Air Force Meteorological Service (www.meteoam.it)

4 OMSZ - Hungarian Meteorological Service (www.met.hu)

5 AGH - University of Science and Technology, Department of Environmental Physics, Krakow, Poland (www.agh.edu.pl)

6 NUI Galway - National University of Ireland, Physics Department, Galway (www.nuigalway.ie)

${ }^{7}$ ENEA (CESI RICERCA until 29 April 2009) - Research on the Electrical System S.p.A., Italy (www.cesiricerca.it)

${ }^{8}$ LSCE - Laboratoire des Sciences du Climat et de l'Environnement, France (www.lsce.ipsl.fr)

${ }^{9}$ UBA - German Environment Agency, Germany (www.umweltbundesamt.de)

All gaps in the observed $\mathrm{CO}_{2}$ mixing ratios were linearly interpolated in time. The autocorrelation analysis was applied for the same set of lag periods $(1-8,18,24,48,72$ and $96 \mathrm{~h}$ ) to the interpolated time series of measured and modelled data in order to quantify the global and the coupled model's capability to capture the fine scale variability in the measured $\mathrm{CO}_{2}$ signals.

\section{Results and discussion}

Figure 2 shows as an example the de-seasonalized time series of the observations together with the simulations by TM3 and TM3-STILT at a flat-terrain station, a mountain station, and a coastal site. The TM3 model produces a smoother time series than TM3-STILT and fails to capture many of fine-scale features of the observed signals, in particular at the Monte Cimone site (CMN). 


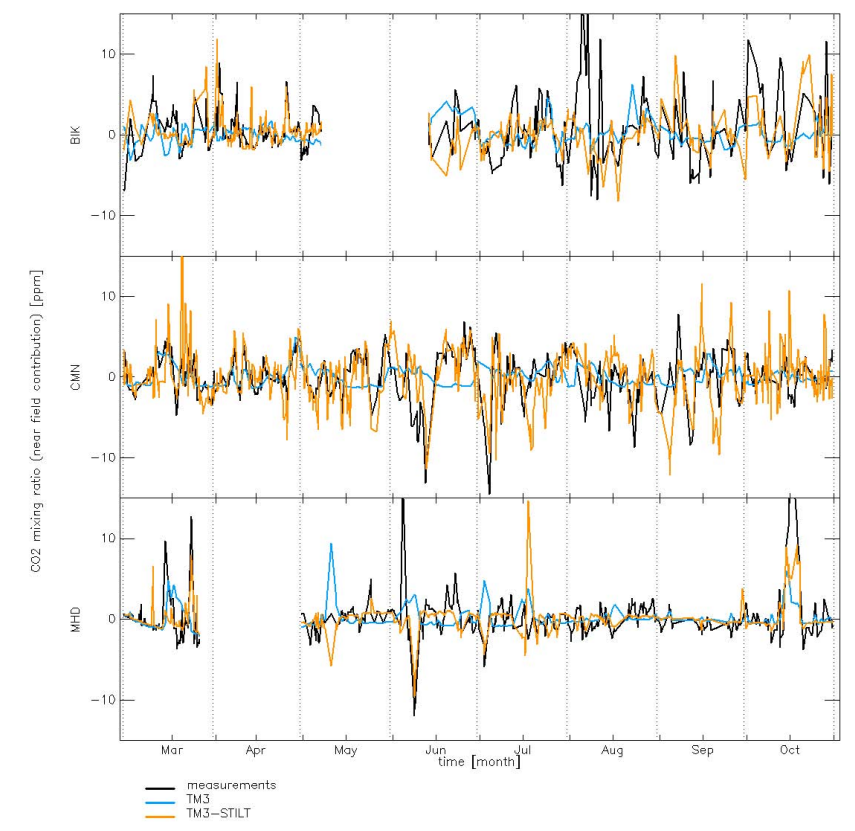

Fig. 2. Time series of the measured and modelled near-field $\mathrm{CO}_{2}$ signal for year 2006 at three locations: BIK - a flat-terrain continental tall tower site in eastern Poland, CMN - a mountain station in Italy, and MHD - coastal station in western Ireland. The seasonal component of the signal has been subtracted from the time series.

\subsection{Analysis of time series using Taylor diagrams}

In order to evaluate the TM3 and TM3-STILT capabilities to capture fine-scale features of modelled signals we make use of Taylor diagrams. The Taylor diagram (Taylor, 2001) shows graphically how closely a pattern matches observations. The similarity of two patterns is qualified in terms of their correlation (angle), their standard deviation (or relative standard deviation - radius), and their root mean square deviation (also root mean square error - distance from the location of pattern to the location of observation on the diagram).

Figure 3 shows Taylor diagrams that demonstrate how well the TM3 and TM3-STILT models are able to simulate the $\mathrm{CO}_{2}$ concentrations at given locations; the match to the observation is shown by the position of each dot. The statistical characteristics used for the Taylor diagrams of Fig. 3 are given in Table 2.

For all sites the TM3-STILT model showed a better correlation of the modelled $\mathrm{CO}_{2}$ time series to observations than the TM3 model (Table 2). Especially large differences were found for the station at Mace Head (MHD), for which the $r_{\mathrm{TM} 3, \mathrm{obs}}=0$ and $r_{\mathrm{STILT}, \mathrm{obs}}=0.63$. The reason for this large difference can be explained by the capability of the TM3-STILT model to resolve the fine-scale transport in this coastal region.

The variance of the TM3-STILT-simulated time series matches the variance of the observations closer than the
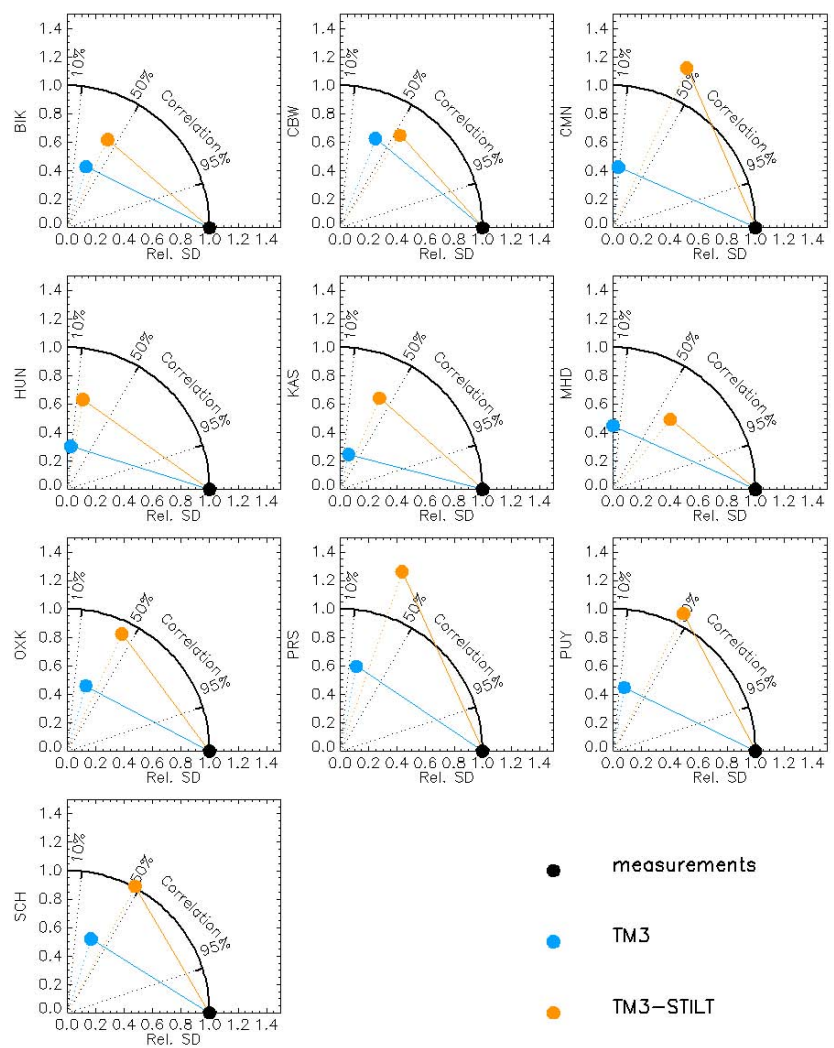

- meosurements

- TM3

TM3-STILT

Fig. 3. Taylor diagrams for modelled and measured time series of $\mathrm{CO}_{2}$ mixing ratio at 10 European sites. The Relative Standard Deviation (Rel. SD) was calculated as the ratio of the SD of modelled time series to the $\mathrm{SD}$ of observations $\left(\mathrm{SD}_{\mathrm{mod}} / \mathrm{SD}_{\mathrm{obs}}\right)$. The black point indicates the perfect match between the model and the observations.

TM3-simulated time series. Good performance of TM3STILT was achieved for CMN, KAS, PUY, OXK, and $\mathrm{SCH}$ as illustrated by the orange dots located close to the Rel.SD=1 line in the Fig. 3. For the BIK, CBW, HUN, and MHD the VarsTILT matches the variance in observations closer than $\operatorname{Var}_{\mathrm{TM} 3}$, however, some of the variability was still missed by the fine-scale model. For the PRS station the regional model produced time series which strongly overestimated the observed variability. This could be explained by an inaccurate placement of the receptor point in the Lagrangian model over the surface with complex terrain: Plateau Rosa is a high-altitude mountain station with a very complex local meteorology that is not adequately represented in either TM3 or TM3-STILT.

The RMSD TM3-STILT $_{\text {was }}$ significantly smaller than RMSD $_{\mathrm{TM} 3}$ for four stations: BIK, CBW, KAS, and MHD. These sites have rather homogeneous surrounding land cover and, except for KAS, are located on flat terrain. Under these conditions the surface flux uncertainly has a minor influence on the atmospheric signal and TM3-STILT with the fineresolved transport over-performes the TM3 model. On the 
Table 2. Statistical characteristics of modelled time series (global mean and seasonal cycle subtracted): $r$ - correlation coefficient, RMSD - Root Mean Square Deviation between observed and modelled time series, and Var - variance of the measured and modelled tile series.

\begin{tabular}{lccccrrr}
\hline \multirow{2}{*}{ Station } & \multicolumn{7}{c}{ Statistical characteristic } \\
\cline { 2 - 8 } & \multicolumn{3}{c}{$r$} & \multicolumn{3}{c}{ RMSD [ppm] } & \multicolumn{3}{c}{ Var [ppm $\left.{ }^{2}\right]$} \\
\cline { 2 - 8 } & TM3 & TM3- & TM3 & TM3- & Meas. & TM3 & TM3- \\
& & STILT & & STILT & & & STILT \\
\hline BIK & 0.30 & 0.42 & 85.71 & 83.72 & 8.23 & 1.65 & 3.81 \\
CBW & 0.37 & 0.54 & 67.30 & 59.81 & 11.09 & 5.03 & 6.64 \\
CMN & 0.09 & 0.42 & 80.15 & 93.02 & 6.84 & 1.25 & 10.45 \\
HUN & 0.09 & 0.17 & 75.97 & 81.25 & 18.57 & 1.71 & 7.64 \\
KAS & 0.24 & 0.40 & 54.44 & 54.21 & 10.03 & 0.64 & 4.90 \\
MHD & 0.00 & 0.63 & 77.56 & 54.71 & 6.06 & 1.22 & 2.44 \\
OXK & 0.27 & 0.42 & 77.89 & 81.39 & 15.08 & 3.41 & 12.28 \\
PRS & 0.19 & 0.33 & 52.94 & 68.53 & 1.89 & 0.70 & 3.37 \\
PUY & 0.17 & 0.45 & 51.35 & 54.65 & 5.76 & 1.18 & 6.76 \\
SCH & 0.31 & 0.47 & 78.13 & 82.20 & 11.96 & 3.57 & 12.21 \\
\hline
\end{tabular}

other hand, at four sites - CMN, PRS, PUY, and SCH RMSD $_{\mathrm{TM} 3-\mathrm{STILT}}$ was greater than RMSD $\mathrm{RM}_{\mathrm{TM}}$. This indicates a greater average mismatch between the TM3-STILT model and the observations. However, this mismatch originates primarily from the larger variability of the TM3-STILT signal predicted for these sites, however the corresponding time series of TM3-STILT are still better correlated to the observations than the estimates by the global model TM3.

\subsection{Autocorrelation analysis}

The autocorrelation analysis of the modelled and measured time series was performed in order to demonstrate the capabilities of the models to represent the statistical properties of the observed $\mathrm{CO}_{2}$ signals. Because of the daytime selection procedure in the model output, the autocorrelation coefficients in the time series of model outputs and observations was calculated only for lag times of 1-8, 18, 24, 48, 72 and $96 \mathrm{~h}$. Since observations were not always available at 1hourly intervals, linearly interpolated values at the respective time lags were used. The associated $95 \%$ confidence intervals for the estimated autocorrelation coefficients were calculated using the Fisher transformation (Shen and Lu, 2006). The confidence intervals are shown as error bars of the autocorrelation coefficients in Fig. 4. The narrow confidence intervals illustrate that the autocorrelation coefficients calculated for the models and the observations become significantly different already from a lag of $1 \mathrm{~h}$ for all sites, except for the PUY and BIK sites.

Figure 4 shows the autocorrelation coefficients and their confidence intervals for the modelled and measured time series of $\mathrm{CO}_{2}$ mixing ratio. For all time series the autocorrelation coefficients were high for short time lags of 1-3 h. As we considered only daytime observations, this strong

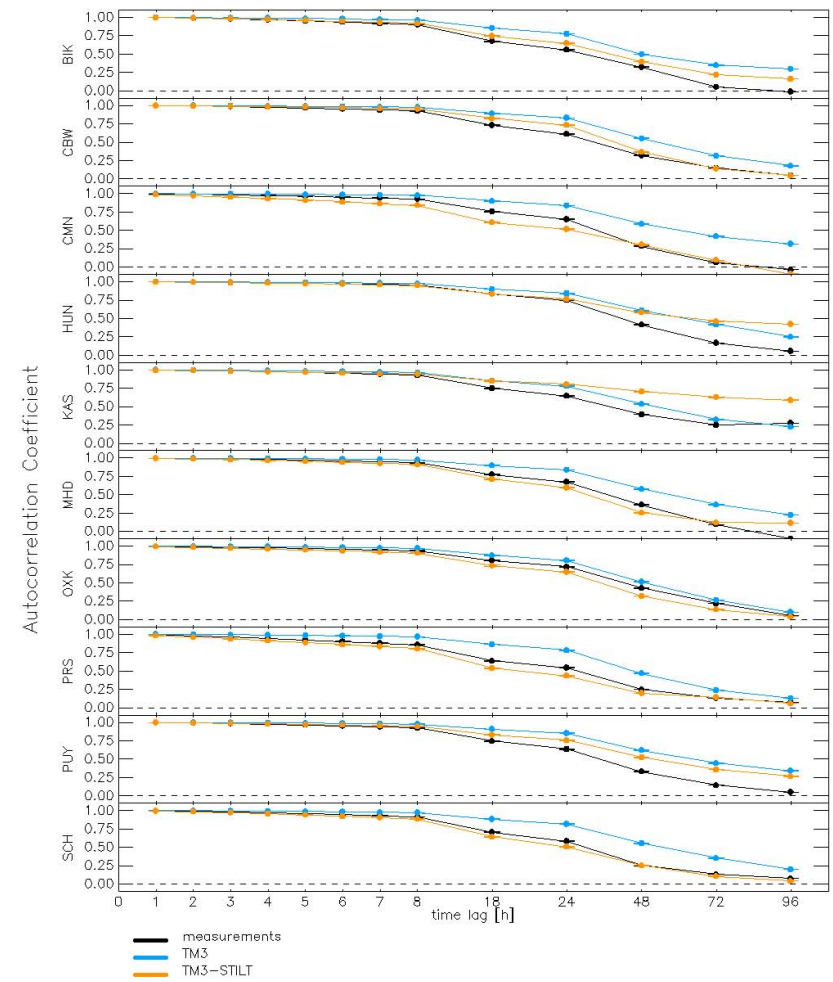

Fig. 4. Autocorrelation coefficients for time series of $\mathrm{CO}_{2}$ mixing ratio $[\mathrm{ppm}]$ measured and modelled at 10 European sites. The time lag of $1,2,3,4,5,6,7,8,18,24,48,72,96 \mathrm{~h}$ was used for day time values between 10:00 and 17:00. Error bars indicate 95\% confidence intervals for the estimated autocorrelation coefficients.

dependence of neighbour values can be explained by small changes of $\mathrm{CO}_{2}$ mixing ratio in $1-3 \mathrm{~h}$ during the day. For the larger time lags of 4 to $8 \mathrm{~h}$ the autocorrelation in observation was slightly decreased for modelled and measured time series.

For time lags greater than $8 \mathrm{~h}$ the TM3 time series still exhibits too high autocorrelation indicating too smoothed out day-to-day variations of tracer mixing ratios (Fig. 4, for BIK, CBW, CMN, MHD, OXK, PRS, PUY, SCH) in contrast to the observations.

The autocorrelation coefficients of the TM3-STILT time series matches much more closely the measurements (Fig. 4) and they are decreasing for time lags greater than 8 hours at almost all sites (except HUN and KAS, Fig. 4), in much better agreement with the observations. This result demonstrates that the TM3-STILT model has a better capability to capture the variability of local fine-scale tracer time series.

The poor behaviour of the autocorrelation curve at the KAS station may be explained by errors in positioning the receptor point at this mountain site. The STILT model requires setting the receptors vertical coordinate as the height above ground, which can be easily measured or estimated. However, the receptor point is placed above the smoothed terrain 
in the model. Therefore, the model output at this sampling height may actually correspond to a different height above sea level (where the observations refer). The positioning of the sampling height remains the major problem for modelling of mountain regions.

\section{Conclusions}

This paper demonstrates a practical implementation and evaluation of the spatial-temporal nesting of a Domain of Interest (DoI) and a Period of Interest (PoI) resolved by a regional model into a global atmospheric transport model. The nesting scheme, previously described in the work of Rödenbeck et al. (2009), was designed for performing high-resolution regional atmospheric trace gas inversions. The fine-resolution regional atmospheric transport model of the Lagrangian type was nested into the Eulerian-grid coarse resolution global model for one year over the European domain. The performance of the nested system versus the global model was analysed for predicting time series of $\mathrm{CO}_{2}$ mixing ratios at ten measurement stations.

The nested high-resolution model system is able to resolve both atmospheric transport and the source/sink patterns of $\mathrm{CO}_{2}$ on fine spatial (less than $\left.1^{\circ}\right)$ and temporal $(1 \mathrm{~h})$ scales and to capture to a considerable degree the fine scale variability in measured signals that is not resolved by the global model.

The illustrative evaluation of the performance of the coupled TM3-STILT model is of course limited. On the one hand, the far field contribution by its construction from a global inversion matches the atmospheric observations outside the DoI. On the other hand, the near-field component of the simulation is dominated by the sources within the DoI. These sources have not been optimized in any way and are expected to contain errors in their spatial and temporal distribution. These errors are added to the atmospheric model transport errors and contribute to the mismatch at the observation stations. The statistical analysis performed here attempts to isolate the former error, but this cannot be done unequivocally.

TM3-STILT constitutes a computationally efficient modelling system for the representation of the high-resolution atmospheric transport of conservative atmospheric tracers over a complex domain such as Europe. In the future, the implemented system is to be used in regional atmospheric inversions for the optimization of high-resolution source flux estimates of $\mathrm{CO}_{2}$ and other long-lived greenhouse gases.
Acknowledgements. The station data were provided and partly funded by European Union projects CARBOEUROPE (Ref. No. GOCE-CT-2003-505572) and CHIOTTO (Ref. No. EVK2-CT-2002-00163). We thank all principal investigators who provided the station data for these projects.

The service charges for this open access publication have been covered by the Max Planck Society.

Edited by: Y. Balkanski

\section{References}

Cundari, V., Colombo, T., and Ciattaglia, L.: 13 Years of Atmospheric Carbon-Dioxide Measurements at Mt-Cimone Station, Italy, Nuovo Cimento C, 18(1), 33-47, 1995.

Derwent, R. G., Ryall, D. B., Manning, A., Simmonds, P. G., O'Doherty, S., and co-authors: Continuous observations of carbon dioxide at Mace Head, Ireland from 1995 to 1999 and its net European ecosystem exchange, Atmos Environ., 36(17), 27992807, 2002.

Gerbig, C., Lin, J. C., Wofsy, S. C., Daube, B. C., Andrews, A. E., and co-authors: Toward constraining regionalscale fluxes of $\mathrm{CO}_{2}$ with atmospheric observations over a continent: 2. Analysis of COBRA data using a receptororiented framework, J. Geophys. Res.-Atmos., 108(D24), 4757, doi:10.1029/2003JD003770, 2003.

Gerbig, C., Körner, S., and Lin, J. C.: Vertical mixing in atmospheric tracer transport models: error characterization and propagation, Atmos. Chem. Phys., 8, 591-602, 2008, http://www.atmos-chem-phys.net/8/591/2008/.

Haszpra, L., Barcza, Z., Hidy, D., Szilagyi, I., Dlugokencky, E., and co-authors: Trends and temporal variations of major greenhouse gases at a rural site in Central Europe, Atmos. Environ., 42(38), 8707-8716, 2008.

Heimann, M. and Körner, S.: The global atmospheric tracer model TM3, in: Technical Reports, Max-Planck-Institut für Biogeochemie, Jena, 1-131. 2003.

Hess, P. G., Flocke, S., Lamarque, J. F., Barth, M. C., and Madronich, S.: Episodic modeling of the chemical structure of the troposphere as revealed during the spring MLOPEX 2 intensive, J. Geophys. Res.-Atmos., 105(D22), 26809-26839, 2000.

Jacobson, A. R., Fletcher, S. E. M., Gruber, N., Sarmiento, J. L., and Gloor, M.: A joint atmosphere-ocean inversion for surface fluxes of carbon dioxide: 1. Methods and global-scale fluxes, Global Biogeochem. Cy., 21(1), GB1020, doi:10.1029/2006GB002703, 2007.

Jung, M., Henkel, K., Herold, M., and Churkina, G.: Exploiting synergies of global land cover products for carbon cycle modeling, Remote Sens. Environ., 101(4), 534-553, 2006.

Kalnay, E., Kanamitsu, M., Kistler, R., Collins, W., Deaven, D., and co-authors: The NCEP/NCAR 40-year reanalysis project, B. Am. Meteorol. Soc., 77(3), 437-471, 1996.

Krol, M., Houweling, S., Bregman, B., van den Broek, M., Segers, A., van Velthoven, P., Peters, W., Dentener, F., and Bergamaschi, P.: The two-way nested global chemistry-transport zoom model TM5: algorithm and applications, Atmos. Chem. Phys., 5, 417432, 2005,

http://www.atmos-chem-phys.net/5/417/2005/. 
Levin, I., Graul, R., and Trivett, N. B. A.: Long-Term Observations of Atmospheric $\mathrm{Co}_{2}$ and Carbon Isotopes at Continental Sites in Germany, Tellus B, 47(1-2), 23-34, 1995.

Lin, J. C., Gerbig, C., Wofsy, S. C., Andrews, A. E., Daube, B. C., and co-authors: A near-field tool for simulating the upstream influence of atmospheric observations: The Stochastic TimeInverted Lagrangian Transport (STILT) model, J. Geophys. Res.Atmos., 108(D16), 4493, doi:10.1029/2002JD003161, 2003.

Lin, J. C. and Gerbig, C.: Accounting for the effect of transport errors on tracer inversions, Geophys. Res. Lett., 32, L01802, doi:10.1029/2004GL021127, 2005.

Longhetto, A., Apadula, F., Bacci, P., Bonelli, P., Cassardo, C., and co-authors: A study of greenhouse gases and air trajectories at Plateau Rosa, Il Nuovo Cimento C, 18(6), 583-601, 1995.

Mahadevan, P., Wofsy, S. C., Matross, D. M., Xiao, X. M., Dunn, A. L., and co-authors: A satellite-based biosphere parameterization for net ecosystem $\mathrm{CO}_{2}$ exchange: Vegetation Photosynthesis and Respiration Model (VPRM), Global Biogeochem Cy., 22(2), GB2005, doi:10.1029/2006GB002735, 2008.

Mikaloff Fletcher, S. E., Gruber, N., Jacobson, A. R., Doney, S. C., Dutkiewicz, S., and co-authors: Inverse estimates of anthropogenic $\mathrm{CO}_{2}$ uptake, transport, and storage by the ocean, Global Biogeochem. Cy., 20(2), GB2002, doi:10.1029/2005GB002530, 2006.

Mikaloff Fletcher, S. E., Gruber, N., Jacobson, A. R., Gloor, M., Doney, S. C., and co-authors: Inverse estimates of the oceanic sources and sinks of natural $\mathrm{CO}_{2}$ and the implied oceanic carbon transport, Global Biogeochem. Cy., 21(1), GB1010, doi:10.1029/2006GB002751, 2007.

Necki, J., Schmidt, M., Rozanski, K., Zimnoch, M., Korus, A., and co-authors: Six-year record of atmospheric carbon dioxide and methane at a high-altitude mountain site in Poland, Tellus B, 55(2), 94-104, 2003.

Olivier, J. G. J., van Aardenne, J. A., Dentener, F., Ganzeveld, L. N., and Peters, J. A. H. W.: Recent trends in global greenhouse gas emissions: regional trends and spatial distribution of key sources, in: Non- $\mathrm{CO}_{2}$ Greenhouse Gases $\left(\mathrm{NCGG}^{-4}\right)$, coordinated by: van Amstel, A., Millpress, Rotterdam, 325-330, 2005.

Pongratz, T., Öttl, D. and Uhrner, U.: Documentation of the Lagrangian Particle Model GRAL (Graz Lagrangian Model) Vs. 6.8. Amt der Steiermärkischen Landesregierung, Fachabteilung 17C, Graz, 1-87, 2008.

Popa, M. E., Gloor, M., Manning, A. C., Jordan, A., Schultz, U., Haensel, F., Seifert, T., and Heimann, M.: Measurements of greenhouse gases and related tracers at Bialystok tall tower station in Poland, Atmos. Meas. Tech., 3, 407-427, 2010, http://www.atmos-meas-tech.net/3/407/2010/.

Pregger, T., Scholz, Y., and Friedrich, R.: Documentation of the Anthropogenic GHG Emission Data for Europe Provided in the Frame of CarboEurope GHG and CarboEurope IP, Final Report CarboEurope-IP, funded by Sixth Framework Programme, IER. IER, University of Stuttgart, Stuttgart, 2007.
Rödenbeck, C.: Estimating $\mathrm{CO}_{2}$ sources and sinks from atmospheric mixing ratio measurements using a global inversion of atmospheric transport. in: Technical Reports, Max-Planck-Institut für Biogeochemie, Jena, 1-48, 2005.

Rödenbeck, C., Gerbig, C., Trusilova, K., and Heimann, M.: A twostep scheme for high-resolution regional atmospheric trace gas inversions based on independent models, Atmos. Chem. Phys., 9, 5331-5342, 2009, http://www.atmos-chem-phys.net/9/5331/2009/.

Rotach, M. W., Gryning, S. E., and Tassone, C.: A two-dimensional Lagrangian stochastic dispersion model for daytime conditions, Q. J. Roy. Meteor. Soc., 122(530), 367-389, 1996.

Schmidt, M., Graul, R., Sartorius, H., and Levin, I.: The Schauinsland $\mathrm{CO}_{2}$ record: 30 years of continental observations and their implications for the variability of the European $\mathrm{CO}_{2}$ budget, J. Geophys. Res.-Atmos., 108(D19), 4619, doi:10.1029/2002JD003085, 2003.

Shen, D. and Lu, Z.: Computation of Correlation Coefficient and Its Confidence Interval in $\mathrm{SAS}^{\complement}$, in: Proceedings of the the Thirtyfirst Annual SAS ${ }^{\circledR}$ Users Group International Conference, San Francisco, California, 26-29 March 2006, http://www2.sas.com/ proceedings/sugi31/170-31.pdf, last access: 26 March 2010, 2006.

Stohl, A., Forster, C., Frank, A., Seibert, P., and Wotawa, G.: Technical note: The Lagrangian particle dispersion model FLEXPART version 6.2, Atmos. Chem. Phys., 5, 2461-2474, 2005, http://www.atmos-chem-phys.net/5/2461/2005/.

Sturm, P., Leuenberger, M., and Schmidt, M.: Atmospheric $\mathrm{O}_{2}$, $\mathrm{CO}_{2}$ and $\delta 13 \mathrm{C}$ observations from the remote sites Jungfraujoch, Switzerland, and Puy de Dôme, France, Geophys. Res. Lett., 32(17), L17811, doi:10.1029/2005GL023304, 2005.

Taylor, K. E.: Summarizing multiple aspects of model performance in a single diagram, J. Geophys. Res.-Atmos., 106(D7), 71837192, 2001.

Thompson, R. L., Manning, A. C., Gloor, E., Schultz, U., Seifert, T., Hänsel, F., Jordan, A., and Heimann, M.: In-situ measurements of oxygen, carbon monoxide and greenhouse gases from Ochsenkopf tall tower in Germany, Atmos. Meas. Tech., 2, 573591, 2009, http://www.atmos-meas-tech.net/2/573/2009/.

Trusilova, K. and Churkina, G.: The Terrestrial Ecosystem Model GBIOME-BGCv1, in: Technical Reports, Max-Planck-Institut für Biogeochemie, Jena, 2008.

van Aardenne, J. A., Dentener, F. J., Olivier, J. G. J., Peters, J. A. H. W., and Ganzeveld, L. N.: The EDGAR 3.2 Fast Track 2000 dataset (32FT2000), 1-12, 2005. 